\title{
Two Grey collections
}

\author{
Christopher de Hamel \\ Director, Medieval Manuscript Collection, Sotheby's Ltd, 34 new Bond Street, London W1, England
}

\begin{abstract}
The author, an expert on medieval manuscripts, recalls how Sir George Grey, successively Governor at the Cape and New Zealand, formed two collections. The first, at the South African Public Library, Cape Town was succeeded by the later collection in Auckland, New Zealand. Interesting examples are given of the most important medieval manuscripts in the two collections. The contrasting strengths and differentiating characteristics of the various categories of manuscripts are assessed, including Bibles, Gospels, illuminated texts, in a variety of languages. The conclusion is reached that the Cape Town collection is superior to the one in the Auckland Public Library.
\end{abstract}

Die outeur verhaal hoe Sir George Grey, wat opeenvolgend Goewerneur in die Kaap en Nieu Zeeland was, twee boekversamelings opgebou het. Die eerste versameling by die Suid-Afrikaanse Biblioteek in Kaapstad is opgevolg deur 'n latere versameling in Auckland, Nieu Zeeland. Interessante voorbeelde word gegee van die belangrikste middeleeuse manuskripte in die twee versamelings. Die kontrasterende sterkpunte en differensiërende eienskappe van die verskillende kategorieë word geëvalueer. Dit sluit Bybels, Evangelies en geïllumineerde tekste in 'n verskeidenheid tale in. Die outeur kom tot die gevolgtrekking dat die Kaapstad-versameling van 'n hoër standaard is as die een in die Auckland Openbare Biblioteek.

Ever since Piet Westra assumed the Directorship of the South African Library in 1981, he has been dreaming of a proper catalogue of the medieval manuscripts presented to the Library in 1861 by Sir George Grey (1812-1898), Governor of the Cape Colony 1854-61. Now, at least, it really seems that the long-awaited catalogue is nearing completion, incorporating the painstaking work of Professor L.F. Casson, Dr Christoph Stroux and Dr Carol Steyn. Its final publication will be one of many monuments to the determination of Piet Westra to place the South African Library on the world stage of scholarship. The Grey Collection will emerge as one of the most interesting and unusual of medieval manuscript libraries in any setting so far from Europe, and the Grey Room will undoubtedly become a centre of research and exhibition. To those of us brought up in New Zealand, however, the Grey Collection and the Grey Room already exist: they are in the Auckland Public Library.

Sir George Grey, in fact, formed two libraries. He gave the first collection to the people of Cape Town in 1861 on his departure from the governorship of the Cape Colony to that of New Zealand. Then he began all over again, and gave the second library to Auckland in 1887. Grey was not especially rich, but he certainly spent much energy in selecting and ordering books. He bought very broadly. Grey clearly wanted to represent a wide range of major texts and of languages, and to provide for the colonies a microcosm of the culture which had formed the civilisation of Europe, and he evidently began (at least) with the same texts at their core.

When the first library was given to Cape Town, especial honour was given to the Greek Gospel Lectionary (4cl): not only are the Gospels the central text of Christianity but the Greek language was (at least to an English Victorian) the well-spring of culture. This was the manuscript which Prince Alfred, second son of Queen Victoria, formally placed on the shelves of the Library when he inaugurated the collection on
18 September 1860 . The Library has a portrait of the prince holding the book, and the volume itself is inscribed with the date on its flyleaf. Intriguingly, then, the very first book acquired by Grey for this second library was an almost identical Greek Gospel Lectionary, bought by post in June 1863 from Quaritch catalogue 190 (1862), no 14 (Auckland G.123). Grey believed it was from Mount Athos - which is unlikely but not impossible - and it was one of the books he proudly showed to visitors throughout the rest of his life. Both the Cape Town and Auckland collections, then grew from Greek Gospel Lectionaries.

In the nineteenth century, the Latin classics were judged hardly inferior to the Gospels as accoutrements of a person of culture. Sir George Grey had bought the Latin historians for Cape Town, including Valerius Maximus (2a24), Lucan (4b9), Caesar (4b12) and Justinus (7b13). Grey actually had his own coat-of-arms inserted into the illumination of the Caesar, a curiously endearing spot of vandalism which shows his attachment to the book. In starting building a collection for Auckland, Grey bought a second Valerius Maximus (Auckland G.144), a Juvenal (G.24) and a manuscript of Boccaccio on the ancient gods of Greek and Rome (G143). All three were bought in 1866 , still only shortly after leaving the Cape. A manuscript of Boccaccio's verse had already been in Cape Town library (3c9). A historical text which evidently caught Grey's imagination was the romantic account of the siege of Troy assembled in the late thirteenth century by Guido della Colonne, the Historia Destructionis Troie. Grey owned three copies, (3c16) (English or perhaps even Scottish in origin), (4b14) (from Savoy) and (4c13) (probably from north-west Italy). It is not a very common text. It cannot simply be chance that Grey bought a fourth copy for Auckland, G.111, copied (this time) in Bohemia.

In the same way, verse manuscripts of the Aurora of Petrus Riga occur both in Cape Town and Auckland in very similar 
copies (4b10 and G.125) and so do manuscripts of the Canzoniere of Petrarch (3c13, 3c22 and G.121). Grey had a manuscript of Boethuis in Cape Town (3c10, from the abbey of Villeneuve-lès-Avignon) and then could not resist for Auckland a French translation of the same text (G.119) with illumination which closely parallels that of $(3 \mathrm{c} 8)$ in Cape Town. Neither library is especially strong in works of the Latin church fathers, but both represent St.Gregory the Great, the Dialogues and Cura pastoralis in Cape Town (6b5) and a marvellous romanespue copy of the Moralia in Auckland (G.132). Pope Gregory had sent the mission to convert the English in 597 and perhaps Grey could identify with the missionaries bringing manuscripts of St Gregory to the ends of the earth.

In Cape Town, Grey had manuscripts in Latin, French, Dutch, German, Italian, Greek and Hebrew; in Auckland he had manuscripts in Latin, French, Italian, Greek and Czech. Two of the very greatest medieval literary texts are in Cape Town but not in Auckland: the Roman de la Rose in French (4c12) and Dante's Divina Commedia in Italian (3c25 and 4b12). Both the Roman de la Rose and the second Dante have faked-up decoration. There is no reason to suppose Grey suspected them, but they may simply have been cheap. Curiously, neither library has any Middle English: even Chaucer could have been bought in the nineteenth century. Was the English language rather unworthy of a great library? Note, however, that there were no fewer than ten manuscripts in Dutch in Cape Town and not a single one in Auckland. The Cape Colony was, of course, English-speaking but probably a concession to the Dutch heritage of other southern Africans prompted Grey to add this unusual ingredient.

The Cape Town Library has more than three times as many manuscripts as that in Auckland. It includes 25 Books of Hours compared with only one in Auckland. It includes seven Latin Bibles compared with only two in Auckland. One of the Cape Town Books of Hours is of superb quality (3c19) but the others vary from good to the very second-rate. As time passed, manuscripts were probably becoming more scarce, but Grey's own taste was also improving. Books of Hours and thirteenth-century Bibles are common texts, and Grey, like many collectors whose libraries evolve, may have felt that run-of-the-mill copies added little. His Book of Hours in Auckland is a good one, used in the Scottish highlands in the Middle Ages (G.146). Grey had been told that one of his Bibles in Auckland was the very copy used by Gutenberg for printing the 42-line Bible (G.128-31) and that the other was in the handwriting of Thomas à Kempis (G.140), both quite fancifull claims, but they were probably bought for this reason rather than simply as Bibles.

Both collections are strong on medieval texts - science and medicine as well as history, literature as well as theology. Both include a few magnificent specimens of illumination, such as the spectacular Amorbach Lectionary in Cape Town (4b3) or the two-volume Missal of Charles de Neufchàtel in Auckland (G.138-9). Both have books once in the princely libraries of the Renaissance, such as the Malatesta (Cape Town 4b8) and the Sforza (Auckland G.121). Both, however, include books with provenances which do not stand up to modern scrutiny, such as the Book of Hours in Cape Town said to have belonged to Marguerite de Valois, queen of Navarre (2a25 - the initials 'MV' simply stand for Maria Virginis) or the Boethuis in Auckland which Grey thought had belonged to Philip the Fair, King of France (G.119 - it is more than a hundred years too late).

Two books alone, however, place the Cape Town collection far ahead of Auckland. We began this short survey with the Gospels in Greek. Grey also bought for Cape Town a vast illustrated manuscript of the Gospels in Latin, written in France in the late ninth century $(4 \mathrm{c} 15)$. There is nothing remotely comparable in any other library of the southern hemisphere. It is one of the oldest western manuscripts outside Europe. Grey also took the Bible back form the Greek and Latin Gospels into the Old Testament in Hebrew and he gave Cape Town a vast Hebrew Bible written in Spain around 1300 (48b2), ornamented with page after page of interlaced carpet-page decoration. Hebrew manuscripts of such richness and refinement are of extreme rarity, and nothing in Auckland could match it.

For one who learned his manuscripts in New Zealand I hate to admit it, but the Grey Collection in Cape Town is better. 